\title{
Supplementum věnované intervenční kardiologii
}

\author{
Michael Aschermann \\ 2. interní klinika kardiologie a angiologie, Všeobecná fakultní nemocnice a 1. lékařská fakulta Univerzity Karlovy, Praha, \\ Česká republika
}

Adresa: prof. MUDr. Michael Aschermann, 2. interní klinika kardiologie a angiologie, VFN a 1. LF UK, U nemocnice 2, 12800 Praha 2, Česká republika, e-mail: mascher@vfn.cz

Před dvěma roky uplynulo již třicet let od první perkutánní koronární balonkové angioplastiky (PTCA), kterou provedl 16. 9. 1977 v Curychu Andreas Roland Grüntzig. V Československu provedl první PTCA již čtyři roky poté, $\mathrm{v}$ roce 1981, profesor Belán se spolupracovníky v IKEM, Praha. Metoda perkutánních intervencí věnčitých tepen (PCI) pak v následujících letech doznala velkého rozvoje v roce 1980 bylo na celém světě provedeno asi 1000 PTCA, $\mathrm{v}$ roce 1995 to bylo již více než 300000 výkonů za rok. $\mathrm{V}$ posledních letech je každým rokem na světě provedeno více než jeden milion koronárních intervencí. Také v České republice jsme od provedení první PTCA dosáhli významného pokroku: ročně je to více než 22000 koronárních intervencí a $\mathrm{z}$ tohoto počtu více než 6000 představují nemocní s akutním infarktem myokardu. V této indikaci jsme dosáhli toho, že PTCA je prováděna jako metoda první volby u více než 90 \% nemocných; v posledních dvou letech se také stále častěji používá aspirační trombektomie a další metody zaměřené na odstranění trombů $\mathrm{z}$ věnčitých tepen. Významně se také zlepšila farmakoterapie akutních koronárních syndromů.

Současně s rozvojem koronárních intervencí dochází v posledním desetiletí také k významnému pokroku ve využití invazivních diagnostických metod a také v perkutánních intervencích v jiných oblastech, než jsou koronární tepny. Z diagnostických metod doznal největšího rozšíření intrakoronární ultrazvuk a od něj odvozená virtuální histologie; nově se používají také optická koherentní tomografie, Ramanova spektroskopie, v diagnostice nestabilních plátů pak intravaskulární termografie, elastografie a palpografie. Vedle toho se $\mathrm{v}$ diagnostice ischemické choroby srdeční využívají metody zaměřené na funkční dopad anatomických změn, např. hodnocení koronárního průtoku a koronární rezervy.

K léčebným intervenčním výkonům, které jsou prováděny mimo koronární tepny, patři alkoholová septální ablace, indikovaná u hypertrofické obstrukční kardiomyopa- tie, atriální septostomie, prováděná u vybraných nemocných s idiopatickou plicní hypertenzí, a katetrizační uzávěry defektů síňového septa různými typy okluderů. $Z$ intervencí prováděných na chlopních má delší historii mitrální valvuloplastika, která představuje metodu volby u správně vybraných nemocných s mitrální stenózou, méně používané jsou komplexní techniky intervencí u mitrální regurgitace. $\mathrm{V}$ posledních letech se $\mathrm{v}$ klinické praxi stále častěji používá perkutánní náhrada aortální chlopně katetrizační technikou. Aortální chlopeň je implantována do oblasti poškozené nativní chlopně v širokém stentu, který je v místě původní chlopně roztažen balonkovým katetrem. Výsledky této náročné procedury jsou při dobře zvolených indikacích výborné.

Je potěšitelné, že v zahraničí je Česká republika v oboru intervenční kardiologie uznávána především pro jasný př́nos v intervenční léčbě akutních koronárních syndromů. Je dobře, že jsme kromě koronárních intervencí začali věnovat více pozornosti také intervencím ostatním. Dnes můžeme proto konstatovat, že zmíněné invazivní a intervenční metody koronární i mimokoronární jsou u nás používány $\mathrm{v}$ plném rozsahu a přispívají $\mathrm{k}$ vysokému standardu péče o naše pacienty s kardiologickými onemocněními. Také to byl jeden $\mathrm{z}$ důvodů, proč jsme pro první supplementum roku 2009 zvolili tuto problematiku. Věŕím, že soubor článků od našich intervenčních kardiologů bude pro kardiology, kteří se intervencemi přímo nezabývají, prrínosem především proto, že právě tito kardiologové mají nemocné po intervenčních výkonech v dlouhodobé péči. Velký dík patří prof. Josefu Veselkovi, který se ujal nelehké úlohy koordinátora tohoto supplementa.

Invazivní diagnostické metody a nové intervenční postupy se v posledních letech významným způsobem rozšířily také do oblasti srdečních arytmií. Připravujeme proto v letošním roce ještě druhé supplementum, které bude věnováno právě novým poznatkům $\mathrm{z}$ oblasti invazivní diagnostiky a intervenční léčby poruch srdečního rytmu. 